\title{
$\gamma$-Aminobutyric Acid and Benzodiazepine Receptor Changes Induced by Unilateral 6-Hydroxydopamine Lesions of the Medial Forebrain Bundle
}

\author{
Helen S. Pan, *John B. Penney, and *Anne B. Young \\ Neuroscience Program and ${ }^{*}$ Department of Neurology, University of Michigan, Ann Arbor, Michigan, U.S.A.
}

\begin{abstract}
Quantitative autoradiography was used to ascertain alterations in $\left[{ }^{3} \mathrm{H}\right]$ muscimol, $\left[{ }^{3} \mathrm{H}\right]$ flunitrazepam (FLU), $\left[{ }^{3} \mathrm{H}\right]$ naloxone, $\left[{ }^{3} \mathrm{H}\right] \mathrm{D}$-alanine-D-leucine-enkephalin (DADL), and $\left[{ }^{3} \mathrm{H}\right]$ spiroperidol binding in basal ganglia 1 week, 4 weeks, and 5 months after unilateral 6hydroxydopamine lesions of the medial forebrain bundle (MFB) in the rat. At 1 and 4 weeks following lesions, $\left[{ }^{3} \mathrm{H}\right]$ spiroperidol binding increased $33 \%$ in striatum. At 5 months, $\left[{ }^{3} \mathrm{H}\right]$ spiroperidol was only nonsignificantly increased above control. At 1 week, $\left[{ }^{3} \mathrm{H}\right]$ muscimol binding decreased $39 \%$ in ipsilateral globus pallidus (GP), but increased $41 \%$ and $11 \%$ in entopeduncular nucleus (EPN) and substantia nigra pars reticulata ( $\mathrm{SNr}$ ), respectively. At 4 weeks, $\left[{ }^{3} \mathrm{H}\right]$ muscimol binding was reduced $19 \%$ in striatum and $44 \%$ in GP and remained enhanced by $32 \%$ in both EPN and SNr. These changes in $\left[{ }^{3} \mathrm{H}\right]$ muscimol
\end{abstract}

binding persisted at 5 months. $\left[{ }^{3} \mathrm{H}\right] \mathrm{FLU}$ binding was altered in the same direction as $\left[{ }^{3} \mathrm{H}\right]$ muscimol binding; however, changes were slower in onset and became significant (and remained so) only at 4 weeks after lesions. Decreases in $\left[{ }^{3} \mathrm{H}\right]$ naloxone and $\left[{ }^{3} \mathrm{H}\right] \mathrm{DADL}$ binding were seen in striatum, GP, EPN, and SNr. Scatchard analyses revealed that only receptor numbers were altered. This study provides biochemical evidence for differential regulation of striatal GABAergic output to GP and EPN/SNr. Key Words: Medial forebrain bundle lesion-GABA receptors-Benzodiazepine receptors-Opiate receptors-Dopamine receptors-Striatal output. Pan H. S. et al. $\gamma$-Aminobutyric acid and benzodiazepine receptor changes induced by unilateral 6-hydroxydopamine lesions of the medial forebrain bundle. J. Neurochem. 45, 1396-1404 (1985).
In recent years, much attention has been given to the afferent and efferent connections of the striatum and the transmitter specificity of these pathways (Dray, 1980; Graybiel and Ragsdale, 1983; Penney and Young, 1983; McGeer et al., 1984). Traditionally, the nigrostriatonigral pathway has been emphasized. Studies of dopaminergic systems reveal that interruption of the nigrostriatal circuit results in behavioral supersensitivity to 3,4-dihydroxyphenylethylamine (DA, dopamine) agonists and increased DA receptor binding in the striatum (Ungerstedt, 1971b; Creese and Snyder, 1979; Staunton et al., 1982; Reches et al., 1983; Neve and Marshall, 1984). Studies of GABAergic systems reveal that damage to striatal efferent cells results in decreased receptor binding in striatum but increased $\gamma$-ami- nobutyric acid (GABA) and benzodiazepine (BDZ) binding in striatal projection areas (Waddington and Cross, 1978, 1980; Pan et al., 1983, 1984a). This increase presumably reflects a compensatory response to loss of GABAergic innervation of the striatal projection areas (Waddington and Cross, 1978, 1980; Guidotti et al., 1979; Shibuya et al., 1980; Biggio et al., 1981; Lo et al., 1983; Pan et al., $1983,1984 a$ ). Lesions or chemical blockade of the nigrostriatal pathway have been found to result in increased turnover of GABA and presumed increased activity of GABAergic striatal neurons (Maggi et al., 1977; Mao et al., 1977; Marco et al., 1978; Schoener and Elkins, 1984). If GABAergic striatal neurons do become more active after nigrostriatal lesions, one would expect subsequent
Received November 26, 1984; accepted May 6, 1985.

Address correspondence and reprint requests to Dr. A. B. Young at Neuroscience Lab. Bldg., 1103 East Huron Street, Ann Arbor, MI 48104, U.S.A.

The present address of Dr. H. S. Pan is Department of Psychiatry, Health Science Center, State University of New York. Stony Brook, NY 11794, U.S.A.
Abbreviations used: BDZ, benzodiazepine; DA, 3,4dihydroxyphenylethylamine (dopamine); DADL, D-alanine-Dleucine-enkephalin; EPN, entopeduncular nucleus; FLU, flunitrazepam; GABA, $\gamma$-aminobutyric acid; GP, globus pallidus; MFB, medial forebrain bundle; 6-OHDA, 6-hydroxydopamine; $\mathrm{SN}$, substantia nigra pars reticulata. 
GABA and BDZ receptor down-regulation in primary striatal projection areas. We investigated this possibility by examining GABA and $\mathrm{BDZ}$ receptors in striatum, globus pallidus (GP), entopeduncular nucleus (EPN), and substantia nigra pars reticulata (SNr) after unilateral 6-hydroxydopamine (6OHDA) lesions of the medial forebrain bundle (MFB).

\section{MATERIALS AND METHODS}

\section{Materials}

Sprague-Dawley rats were supplied by Spartan Animal. Desipramine was a gift from the Merrell Dow Research Institute. Radioligands were obtained from Amersham. Other chemicals were purchased from Sigma. Ultrofilm ${ }^{3} \mathrm{H}$ was purchased from LKB Instruments.

\section{Lesions}

Male Sprague-Dawley rats weighing $145-155 \mathrm{~g}$ were anesthetized with xylazine-ketamine, $5 \mathrm{mg}: 80 \mathrm{mg} / \mathrm{kg}$, i.p., and placed in a Kopf small animal stereotaxic device. At 30-60 min prior to 6-OHDA injections, the rats were pretreated with $15 \mathrm{mg} / \mathrm{kg}$ i.p. desipramine, to prevent lesion of the noradrenergic fibers (Breese and Traylor, 1971; Wooten and Collins, 1981, 1983). A thin-wall 30-gauge stainless steel cannula containing $2 \mathrm{mg} / \mathrm{ml}$ 6-OHDA $\cdot \mathrm{HBr}$ and $0.001 \%$ ascorbic acid in saline (kept at $4^{\circ} \mathrm{C}$ in the dark until loaded) was lowered through a burr hole in the skull to a site near the MFB using the following coordinates with the incisor bar $5 \mathrm{~mm}$ above the interaural line: $1.5 \mathrm{~mm}$ posterior, $1.3 \mathrm{~mm}$ lateral, and $8.0 \mathrm{~mm}$ ventral to bregma (AP $4.4 \mathrm{~mm}$, ML $1.2 \mathrm{~mm}$, and DV $-2.5 \mathrm{~mm}$ in the atlas of Konig and Klippel, 1963). One minute after the placement of the cannula, $4 \mu$ l of 6-OHDA were injected at a rate of $0.5 \mu \mathrm{l} / \mathrm{min}$ for $8 \mathrm{~min}$ (total dose, $8 \mu \mathrm{g}$ of 6-OHDA $\cdot \mathrm{HBr}$ ). The cannula was left in place for 2 min after the injection and then removed.

\section{Terminal degeneration studies and histology}

Four days after surgery, three 6-OHDA lesioned and three vehicle-injected control rats were perfused intracardially with $2 \%$ glutaraldehyde and $0.5 \%$ formalin in phosphate buffer, $\mathrm{pH}$ 7.4. The perfused brains were removed, cryoprotected by immersion in $30 \%$ sucrose in phosphate buffer, $\mathrm{pH} 7.4$, and sectioned on a freezing microtome at $25 \mu \mathrm{m}$. Silver impregnation of degenerating axons and terminals was carried out by exposing the sections in sequence to $0.025 \%$ potassium permanganate for $5 \mathrm{~min}, 1 \%$ oxalic acid- $1 \%$ hydroquinone solution for $1-2$ min, $2.5 \%$ uranyl nitrate for $5 \mathrm{~min}, 0.2 \%$ silver nitrate for $90 \mathrm{~min}$, and $0.83 \%$ silver nitrate- $32 \%$ ethanol-5.5\% ammonium hydroxide- $0.125 \%$ sodium hydroxide for $2-5$ min with thorough rinses between each solution. Without rinsing, the sections were then transferred to a reducing solution of $8.55 \%$ ethanol- $0.27 \%$ citric acid for $162 \mathrm{~min}$, then rinsed, fixed in $0.5 \%$ sodium thiosulfate for $1 \mathrm{~min}$, rinsed again, mounted, dehydrated, and enclosed (Fink and Heimer, 1967). Adjacent sections were stained with cresyl violet. In addition, nigral sections adjacent to the ones that produced the autoradiograms were fixed over paraformaldehyde vapors overnight at room temperature and stained with cresyl violet.

\section{$\left[{ }^{3} \mathrm{H}\right] \mathrm{DA}$ uptake}

At 1 week, 4 weeks, and 5 months after the lesions, rats were killed by decapitation. The brains were quickly removed. One-millimeter slices of rostral striatum were removed. The caudate/putamen, nucleus accumbens, and olfactory tubercle (ipsi- and contralateral to the side of the lesion) were removed en bloc while on ice and used in $\left.{ }^{3} \mathrm{H}\right] \mathrm{DA}$ uptake studies to assess the effectiveness of the lesion (Kuhar, 1973). The tissue was homogenized by 10 passes with a Teflon pestle (clearance $0.0045-0.0065$ inches), suspended in $3 \mathrm{ml}$ ice-cold $0.32 M$ sucrose in phosphate buffer $(\mathrm{pH} 7.4)$, and centrifuged at $4^{\circ} \mathrm{C}$ at $20,000 \mathrm{~g}$ for $20 \mathrm{~min}$. Pellets were resuspended in $2 \mathrm{ml}$ buffered sucrose. Aliquots $(0.2 \mathrm{ml})$ of crude synaptosomes were incubated in $0.8 \mathrm{ml} 12 \mathrm{n} M\left[{ }^{3} \mathrm{H}\right] \mathrm{DA}$ in Dulbecco's phosphate-buffered saline with $0.02 \%$ ascorbic acid $\left(\mathrm{pH} \mathrm{7.4)}\right.$ at $4^{\circ} \mathrm{C}$ (nonspecific uptake) or at $37^{\circ} \mathrm{C}$ for 4 min. Uptake was terminated by centrifugation at $4^{\circ} \mathrm{C}$ $(48,000 \mathrm{~g}$ for $10 \mathrm{~min})$. The pellets were rinsed with $8 \mathrm{ml}$ ice-cold saline and centrifuged again at $48,000 \mathrm{~g}$ for 10 min. The pellets were solubilized in $0.5 \mathrm{ml} \mathrm{NCS}$ and then $5 \mathrm{ml}$ ACS was added to each tube. Liquid scintillation spectroscopy was used to determine the amount of $\left[{ }^{3} \mathrm{H}\right] \mathrm{DA}$ taken up by the synaptosomes. Only animals with $>90 \%$ reduction in specific uptake were then used in the receptor assay (Heikkila et al., 1981).

\section{Autoradiography}

After the removal of striatal slices for $\left[{ }^{3} \mathrm{H}\right] \mathrm{DA}$ uptake, the brains were quickly frozen on powdered dry ice as described previously (Pan et al., 1983). Coronal $20-\mu \mathrm{m}$ sections were cut at $-15^{\circ} \mathrm{C}$ and thaw-mounted onto gelatin-coated slides. $\left[{ }^{3} \mathrm{H}\right]$ Spiroperidol binding was performed as described previously by Pan et al. (1984a). To measure $\left[{ }^{3} \mathrm{H}\right]$ muscimol and $\left[{ }^{3} \mathrm{H}\right]$ flunitrazepam $\left.\left({ }^{3} \mathrm{H}\right] \mathrm{FLU}\right)$ binding, prewashed sections were incubated in 7-100 $\mathrm{nM}$ $\left[{ }^{3} \mathrm{H}\right]$ muscimol at $4^{\circ} \mathrm{C}$ for $30 \mathrm{~min}$ or $0.5-15 \mathrm{nM}\left[{ }^{3} \mathrm{H}\right] \mathrm{FLU}$ at $37^{\circ} \mathrm{C}$ for $30 \mathrm{~min}$. Nonspecific binding of $\left[{ }^{3} \mathrm{H}\right]$ muscimol and $\left[{ }^{3} \mathrm{H}\right] \mathrm{FLU}$ was determined in the presence of $10^{-4} M$ GABA and $5 \times 10^{-6} M$ clonazepam, respectively. $\left[{ }^{3} \mathrm{H}\right]$ Naloxone and $\left[{ }^{3} \mathrm{H}\right]_{\mathrm{D}-a l a n i n e-D-l e u c i n e-e n k e p h a l i n}$ ( $\left.\left[{ }^{3} \mathrm{H}\right] \mathrm{DADL}\right)$ binding was studied by the second method of Abou-Khalil et al. (1984).

In striatum, GP, and SNr, full Scatchard analyses were performed. For EPN, $\left[{ }^{3} \mathrm{H}\right]$ muscimol and $\left[{ }^{3} \mathrm{H}\right] \mathrm{FLU}$ binding was done at three concentrations $(100 \mathrm{nM}, 50 \mathrm{nM}$, and $25 \mathrm{n} M$ for muscimol and $15 \mathrm{n} M, 7 \mathrm{n} M$, and $3.5 \mathrm{n} M$ for FLU). The ratios of binding in EPN on the side of the lesion to that on the intact side at each concentration were averaged. Analysis of $\left.{ }^{3} \mathrm{H}\right]$ naloxone $(3$ and $6 \mathrm{n} M)$. $\left[{ }^{3} \mathrm{H}\right]$ DADL $(3$ and $6 \mathrm{n} M)$, and $\left[{ }^{3} \mathrm{H}\right]$ spiroperidol $(1 \mathrm{n} M, 0.5$ $\mathrm{n} M, 0.3 \mathrm{n} M$, and $0.1 \mathrm{n} M$ ) binding in EPN was performed similarly. After incubation all slides were rinsed to remove unbound radioligand, dried, and exposed to Ultrofilm ${ }^{3} \mathrm{H}$ (LKB) along with standards as described by Pan et al. $(1983,1984 a)$.

\section{Analysis of autoradiograms}

Densitometry was performed using a low-cost spot densitometer developed by Dauth et al. (1983). Eight to sixteen readings of the optical density were made from each area of interest. These readings were compared to those from standards equivalent to tissue containing known amounts of tritium (Pan et al., 1983) and the con- 
centration of tritium in the area of interest calculated by a computer-generated polynomial equation. The values obtained from serial sections incubated in different concentrations of ligand or of displacing drug were analyzed by saturation analysis to determine the number and affinity of receptors (Pan et al., 1983).

\section{Area measurements of striatum, GP, and $\mathrm{SNr}$}

To assess any receptor density changes caused by postor transsynaptic tissue shrinkage due to denervation, area measurements of striatum, GP, and $\mathrm{SNr}$ ipsi- and contralateral to the lesion were made from autoradiographic images by the method of Pan et al. (1984b). For each structure, area measurements from 5 to 10 serial sections spanning $100-200 \mu \mathrm{m}$ were taken. The ratio between structures ipsi- and contralateral to the lesion was used as an index for shrinkage.

\section{RESULTS}

\section{Terminal degeneration studies and histology}

In Fink-Heimer (1967) fiber degeneration studies of animals killed 4 days after vehicle or 6-OHDA MFB injections, a few degenerating fibers were found along the needle tract in cortex, hippocampus, stria medullaris, habenula, and ventral thalamus. The needle tracts ended in the hypothalamus dorsal to the MFB. In the 6-OHDA-treated animals, additional degenerating fibers were seen in the rostral MFB and striatum. Some degenerating terminals were found in nucleus accumbens and rostral cortex of the 6-OHDA-treated rats as well. Only a few scattered degenerating fibers were seen in substantia nigra of the 6-OHDA-treated rats.

Nigral sections adjacent to the ones that produced the Fink-Heimer stains (or the autoradiograms) were stained with cresyl violet. Large neurons in substantia nigra pars compacta on the side of the lesion had largely disappeared and had been replaced by a small cell infiltrate. Neurons in the substantia nigra contralateral to the lesion were preserved (Fig. 1). Cell groups in other areas of the brain were spared.

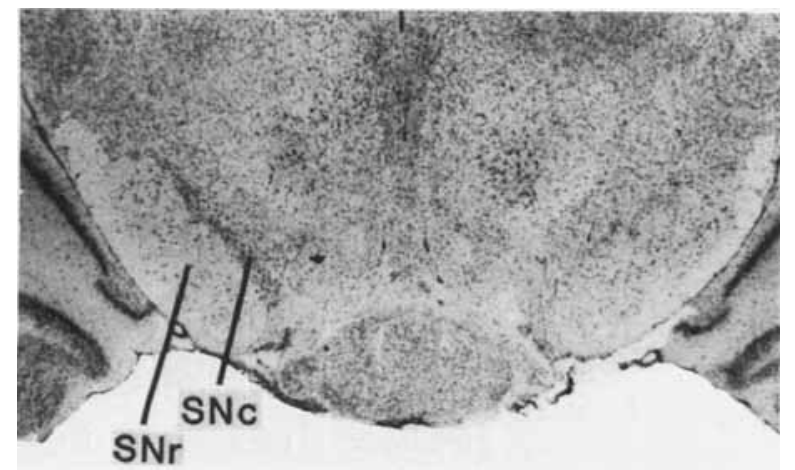

FIG. 1. A photomicrograph of a cresyl violet-stained nigral section in a rat 1 week after receiving a 6-OHDA lesion in the right MFB. There was a dramatic reduction in cell number in substantia nigra pars compacta (SNc) whereas cells in substantia nigra pars reticulata (SNr) were unaffected. $\times 11$

\section{Autoradiography}

Changes in $\left[{ }^{3} \mathrm{H}\right]$ spiroperidol binding are summarized in Figs. 2 and 3. One week after lesions, $\left[{ }^{3} \mathrm{H}\right]$ spiroperidol binding was increased in striatum by $33 \pm 2 \%$. This increase persisted at 4 weeks but returned slightly toward normal at 5 months.

Figures 4 and 5 and Table 1 summarize changes in $\left[{ }^{3} \mathrm{H}\right]$ muscimol and $\left[{ }^{3} \mathrm{H}\right] \mathrm{FLU}$ binding 1 week, 4 weeks, and 5 months after lesions. One week following lesions, $\left[{ }^{3} \mathrm{H}\right]$ muscimol binding was decreased in ipsilateral GP by $39 \pm 3 \%$ compared to that of control; but was increased in EPN by $41 \pm$ $21 \%$ and in $\mathrm{SNr}$ by $11 \pm 4 \%$. At 4 weeks, $\left[{ }^{3} \mathrm{H}\right]$ muscimol binding was decreased in striatum by $19 \pm 2 \%$ and in GP by $44 \pm 6 \%$ but was increased in EPN by $32 \pm 12 \%$ and in $\mathrm{SNr}$ by $32 \pm 13 \%$. These changes in $\left[{ }^{3} \mathrm{H}\right]$ muscimol binding persisted or increased in magnitude in all areas 5 months after lesions. Binding in layer IV of cortex and stratum moleculare of hippocampus was not affected by the lesions.

For $\left[{ }^{3} \mathrm{H}\right] \mathrm{FLU}$ binding, no receptor changes were observed until 4 weeks after lesion. At this time, $\left[{ }^{3} \mathrm{H}\right] \mathrm{FLU}$ binding decreased in GP by $51 \pm 5 \%$, but binding was increased in EPN by $15 \pm 3 \%$ and in $\mathrm{SNr}$ by $24 \pm 6 \%$. In animals that survived 5 months, decreased binding in striatum $(18 \pm 2 \%)$ was observed in addition to changes in GP, EPN, and SNr. Measurements of binding in layer IV of cerebral cortex and stratum moleculare of hippocampus were symmetric.

For $\left[{ }^{3} \mathrm{H}\right]$ muscimol and $\left[{ }^{3} \mathrm{H}\right]$ FLU binding, Scatchard analyses revealed that only receptor numbers were altered; the binding affinities were unchanged.

A summary of changes in opiate receptor binding is given in Fig. 6 and Table 2. One week after lesions, $\left[{ }^{3} \mathrm{H}\right]$ naloxone and $\left[{ }^{3} \mathrm{H}\right] \mathrm{DADL}$ binding were decreased in "nonpatch" striatum by $31 \pm 4 \%$ and

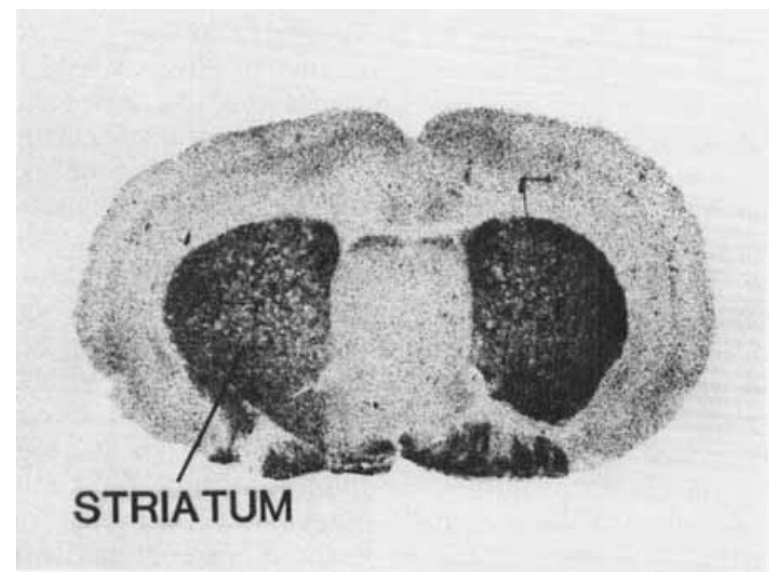

FIG. 2. An autoradiogram of $\left[{ }^{3} \mathrm{H}\right]$ spiroperidol $(0.5 \mathrm{nM})$ binding in a coronal section of the striatum 4 weeks after 6OHDA lesion in the right MFB. The striatum ipsilateral to the lesioned MFB had increased binding. $\times 5$. 


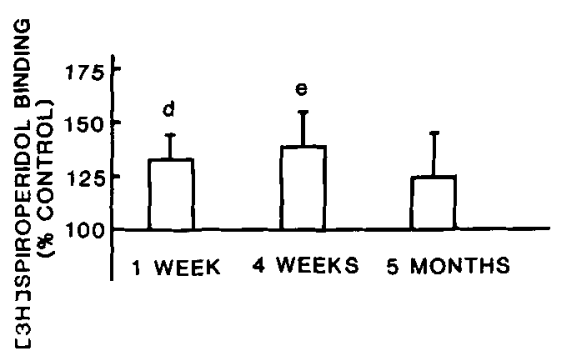

FIG. 3. Bar graphs of $\left[{ }^{3} \mathrm{H}\right]$ spiroperidol binding in striatum after unilateral 6-OHDA lesions. Increased binding in striatum ipsilateral to the lesion was seen 1 week and 4 weeks after lesions. Binding is represented as percent of binding on the intact side. Significance levels are: $d, p<$ $0.05 ; \mathrm{e}, \mathrm{p}<0.1$; two-tailed paired Student's $t$ test.

$49 \pm 5 \%$, respectively, and in GP by $40 \pm 5 \%$ and $57 \pm 10 \%$, respectively. At 4 weeks, $\left[{ }^{3} \mathrm{H}\right]$ naloxone binding was decreased in EPN by $19 \pm 1 \%$ and $\left[{ }^{3} \mathrm{H}\right] \mathrm{DADL}$ binding was decreased by $7 \pm 1 \%$ in SNr. In animals that survived for 5 months, $\left[{ }^{3} \mathrm{H}\right]$ naloxone binding in $\mathrm{SNr}$ was decreased by 32 $\pm 2 \%$. Changes in $\left[{ }^{3} \mathrm{H}\right]$ naloxone binding in striatal patches were not quantitated; however, there was a gradual and almost complete disappearance of $\mu$ opiate receptor patches in the striatum ipsilateral to the lesion by 5 months.
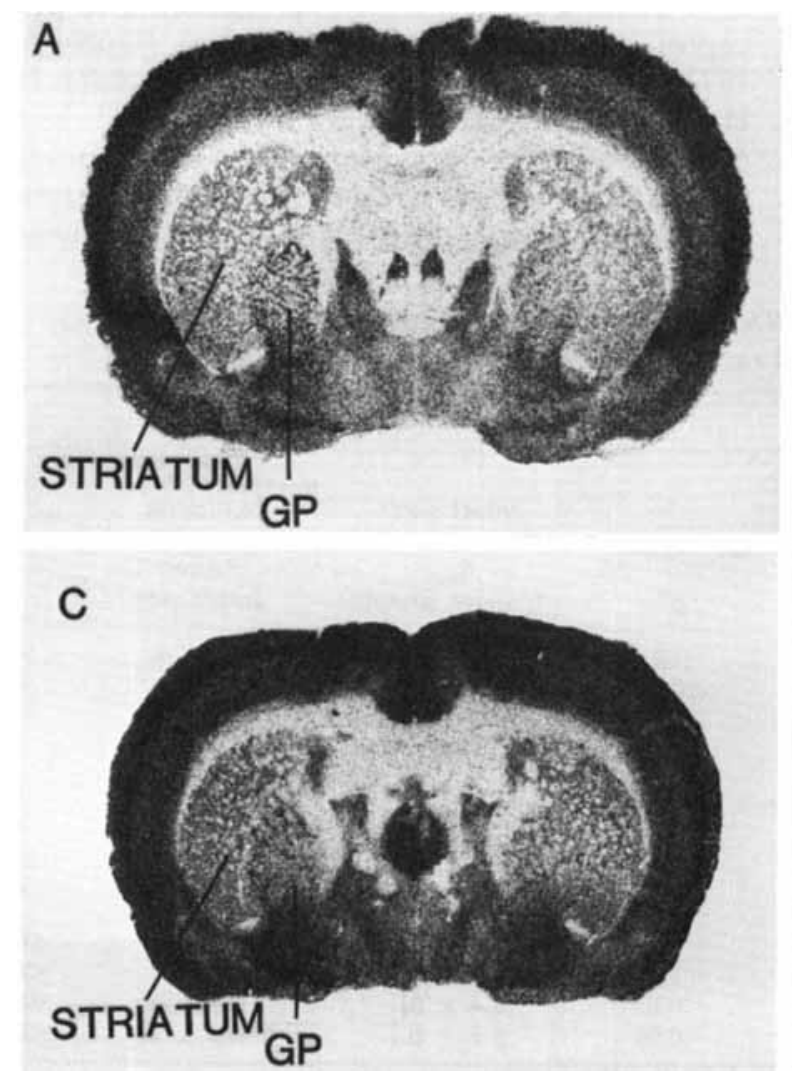

Area measurements of striatum, GP, and $\mathrm{SNr}$

At 1 week as well as 5 months after the lesions, cross-sectional area measurements of striatum, GP, and substantia nigra ipsi- and contralateral to the lesion were taken. No statistically significant changes were observed in either denervated striatum or striatal projection areas.

\section{DISCUSSION}

The neurochemical specificity of the afferent and efferent connections of the striatum have been studied extensively. The dopaminergic nigrostriatal pathway arises from large neurons in the substantia nigra pars compacta (Dahlstrom and Fuxe, 1964; Ungerstedt, 1971a). DA fibers travel in the MFB, with noradrenergic and 5-hydroxytryptamine (serotonin) fibers, to terminate in the caudate and putamen (Dahlstrom and Fuxe, 1964; Ungerstedt, 1971a). DA affects the activity of GABAergic striatal output neurons directly and probably indirectly via cholinergic interneurons (Stradler et al., 1973; Hattori et al., 1976; Maggi et al., 1977; Mao et al., 1977; Marco et al., 1978). Tyrosine hydroxylase, the rate-limiting enzyme in DA synthesis, is found in presynaptic terminals located on spiny neurons in the striatum (Pickel et al., 1981). The
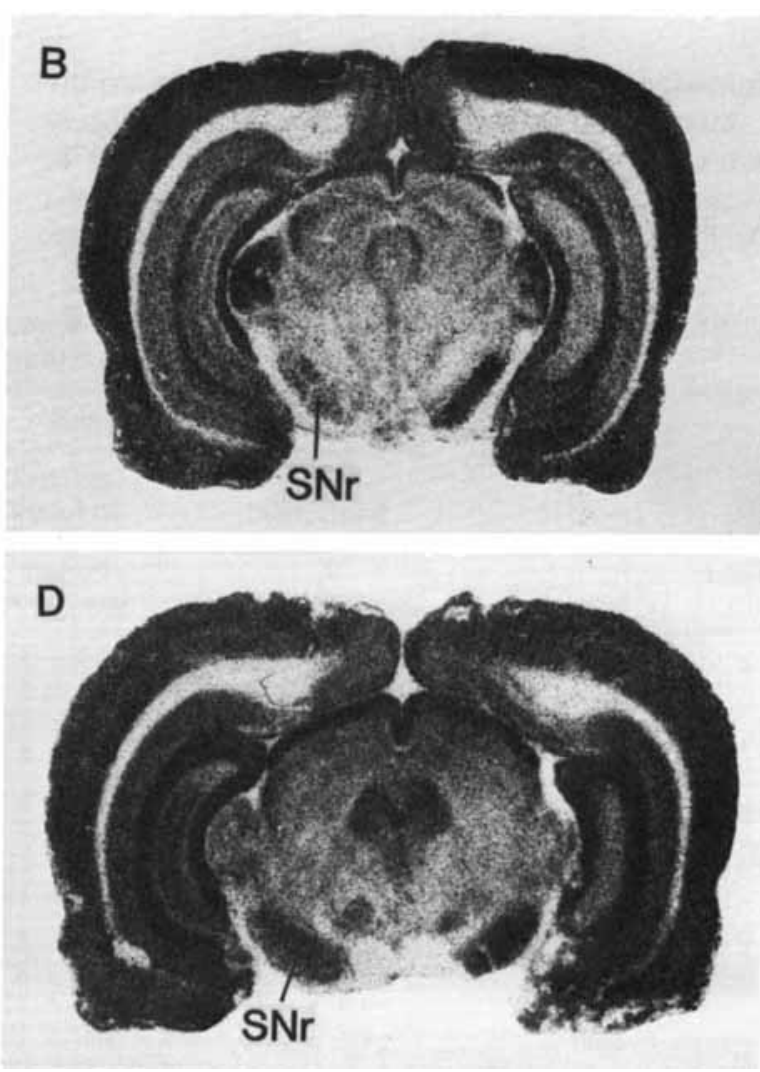

FIG. 4. Autoradiograms of coronal sections showing $\left[{ }^{3} \mathrm{H}\right]$ muscimol $(50 \mathrm{nM})$ binding in $\mathrm{GP}(\mathrm{A})$ and $\mathrm{SNr}(\mathrm{B})$ and $\left[{ }^{3} \mathrm{H}\right] \mathrm{FLU}(7 \mathrm{nM})$ binding in GP (C) and SNr (D) 4 weeks after 6-OHDA lesions in the right MFB. Binding for both ligands was decreased in GP but was increased in $\mathrm{SNr}$ ipsilateral to the lesion. $\times 5$. 

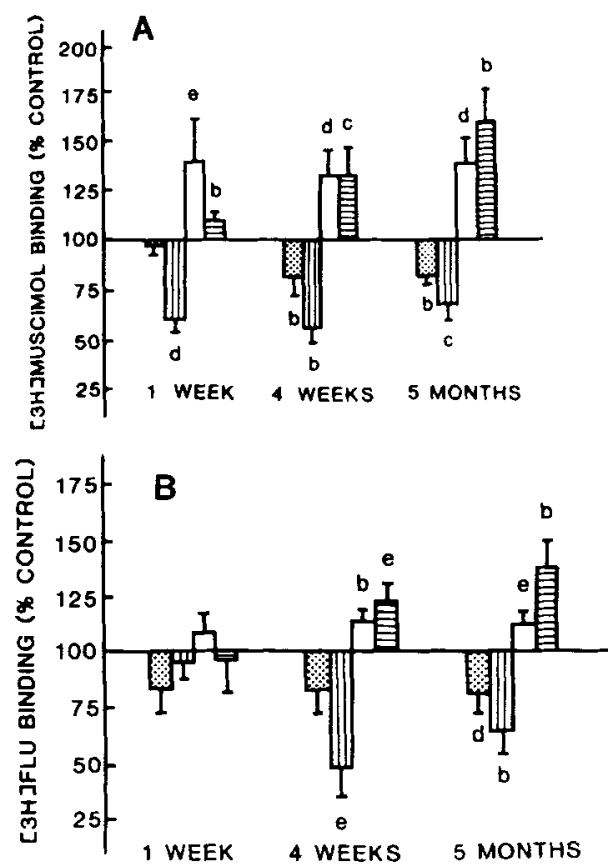

FIG. 5. Bar graphs of $\left[{ }^{3} \mathrm{H}\right]$ muscimol (A) and $\left[{ }^{3} \mathrm{H}\right] \mathrm{FLU}(\mathbf{B})$ binding in striatum, GP, EPN, and SNr 1 week, 4 weeks, and 5 months after unilateral 6-OHDA MFB lesions. Binding in denervated striatum (stippled bars) and GP (vertical lines) was affected differently from that in EPN (open bars) and $\mathrm{SNr}$ (horizontal lines). Significance levels: $b, p<0.01 ; c, p$ $<0.02 ; d, p<0.05 ; e, p<0.1$; two-tailed paired Student's $t$ test.

medium-sized spiny striatal efferent neurons are the most prevalent striatal neuronal type and are largely GABAergic (Grofova, 1975; Fonnum et al., 1978; Nagy et al., 1978; Park et al., 1980; Somogyi et al., 1981). They are noted for their extensive network of local recurrent collaterals. Although previously it had been thought that these neurons project to GP, EPN, and SNr via axon collaterals (Preston et al., 1980), recent data support the existence of distinct striatopallidal and striatonigral pathways (Parent et al., 1984; Feger and Crossman, 1984).

The effects of striatal lesions on GABA, BDZ, and $\delta$ - and $\mu$-opiate receptors have been described. Both high- and low-affinity GABA receptors upregulate in striatal projection areas after striatal lesions (Waddington and Cross, 1978, 1980; Guidotti et al. 1979; Waszczak et al., 1981; Pan et al., 1983). $\mathrm{BDZ}$ receptors also up-regulate after striatal lesions (Shibuya et al., 1980; Biggio et al., 1981; Lo et al., 1983; Pan et al., 1984a); however, the time course of $\mathrm{BDZ}$ receptor changes is slower than that for GABA receptors (Pan et al., 1984a). In contrast, opiate receptors (both $\mu$ and $\delta$ ) decrease in striatum and its projection areas after striatal lesions (AbouKhalil et al., 1984). Although no direct proof is available, these findings are consistent with the postsynaptic localization and up-regulation of GABA and BDZ receptors and the presynaptic (terminal) localization of opiate receptors.

To gain additional information on the regulation of striatal efferent pathways, we decided to study neurotransmitter receptors in basal ganglia after lesions of the nigrostriatal pathway. Numerous investigators have demonstrated up-regulation of DA receptors after MFB 6-OHDA lesions (Ungerstedt, 1971 a; Creese et al., 1977; Creese and Snyder, 1979; Heikkila et al., 1981; Staunton et al., 1982; Reches et al., 1983; Neve and Marshall, 1984). Up-regulation has been observed consistently only in animals with $>90 \%$ lesions of the nigrostriatal pathway as

TABLE 1. Time course of changes in $\left[^{3} \mathrm{H}\right]$ muscimol and $l^{3} H J F L U$ binding in striatum and its projection areas in $M F B$-lesioned rat brains

\begin{tabular}{|c|c|c|c|c|c|c|c|}
\hline \multirow[b]{3}{*}{$\begin{array}{l}\text { Time after } \\
\text { lesions }\end{array}$} & \multirow[b]{3}{*}{ Structures } & \multicolumn{3}{|c|}{$\left[{ }^{3} \mathrm{H}\right]$ Muscimol } & \multicolumn{3}{|c|}{$\left[{ }^{3} \mathrm{H}\right] F L U$} \\
\hline & & Intact side ${ }^{a}$ & $\begin{array}{l}\text { Ipsilateral } \\
\text { to lesion }\end{array}$ & & Intact side $^{a}$ & $\begin{array}{l}\text { Ipsilateral } \\
\text { to lesion }\end{array}$ & \\
\hline & & $\begin{array}{c}B_{\max } \\
\text { (pmol/mg protein) }\end{array}$ & $\begin{array}{l}\text { Percent } \\
\text { intact side }\end{array}$ & $\mathrm{p}^{h}$ & $\begin{array}{c}\boldsymbol{B}_{\max } \\
(\mathrm{pmol} / \mathrm{mg} \text { protein) }\end{array}$ & $\begin{array}{l}\text { Percent } \\
\text { intact side }\end{array}$ & \\
\hline 1 week & $\begin{array}{l}\text { Striatum } \\
\text { GP } \\
\text { EPN } \\
\text { SNr }\end{array}$ & $\begin{array}{l}2.0 \pm 0.3 \\
2.8 \pm 0.5 \\
0.5 \pm 0.1 \\
4.9 \pm 0.5\end{array}$ & $\begin{aligned} 99 & \pm 5 \\
61 & \pm 5 \\
141 & \pm 21 \\
111 & \pm 4\end{aligned}$ & $\begin{array}{l}\text { NS } \\
<0.05 \\
<0.10 \\
<0.01\end{array}$ & $\begin{array}{l}1.6 \pm 0.3 \\
1.7 \pm 0.2 \\
0.7 \pm 0.1 \\
2.8 \pm 0.7\end{array}$ & $\begin{aligned} 82 & \pm 8 \\
94 & \pm 7 \\
107 & \pm 10 \\
94 & \pm 18\end{aligned}$ & $\begin{array}{l}\text { NS } \\
\text { NS } \\
\text { NS } \\
\text { NS }\end{array}$ \\
\hline 4 weeks & $\begin{array}{l}\text { Striatum } \\
\text { GP } \\
\text { EPN } \\
\text { SNr }\end{array}$ & $\begin{array}{l}2.0 \pm 0.2 \\
2.6 \pm 0.2 \\
0.7 \pm 0.1 \\
4.1 \pm 0.5\end{array}$ & $\begin{aligned} 81 & \pm 9 \\
56 & \pm 7 \\
132 & \pm 12 \\
132 & \pm 13\end{aligned}$ & $\begin{array}{l}<0.01 \\
<0.01 \\
<0.05 \\
<0.02\end{array}$ & $\begin{array}{l}1.1 \pm 0.2 \\
1.8 \pm 0.4 \\
0.7 \pm 0.1 \\
2.0 \pm 0.4\end{array}$ & $\begin{aligned} 84 & \pm 10 \\
49 & \pm 11 \\
115 & \pm 3 \\
124 & \pm 6\end{aligned}$ & $\begin{array}{l}\text { NS } \\
<0.10 \\
<0.01 \\
<0.10\end{array}$ \\
\hline 5 months & $\begin{array}{l}\text { Striatum } \\
\text { GP } \\
\text { EPN } \\
\text { SNr }\end{array}$ & $\begin{array}{l}2.5 \pm 0.3 \\
2.7 \pm 0.1 \\
0.9 \pm 0.1 \\
4.1 \pm 0.4\end{array}$ & $\begin{array}{c}82 \pm 3 \\
68 \pm 8 \\
140 \pm 12 \\
160 \pm 17\end{array}$ & $\begin{array}{l}<0.01 \\
<0.02 \\
<0.05 \\
<0.01\end{array}$ & $\begin{array}{l}1.1 \pm 0.2 \\
1.9 \pm 0.1 \\
0.4=0.1 \\
3.0 \pm 0.7\end{array}$ & $\begin{aligned} 82 & \pm 6 \\
67 & \pm 7 \\
113 & \pm 6 \\
139 & \pm 10\end{aligned}$ & $\begin{array}{l}<0.05 \\
<0.01 \\
<0.10 \\
<0.01\end{array}$ \\
\hline
\end{tabular}

Data represent the means \pm SEM of four to eight animals.

${ }^{a}$ For EPN, values represent amount bound at $100 \mathrm{nM}\left[{ }^{3} \mathrm{H}\right]$ muscimol or $15 \mathrm{n} M\left[{ }^{3} \mathrm{H}\right] \mathrm{FLU}$.

${ }^{b}$ Two-tailed paired Student's $t$ test; NS. not significant. 

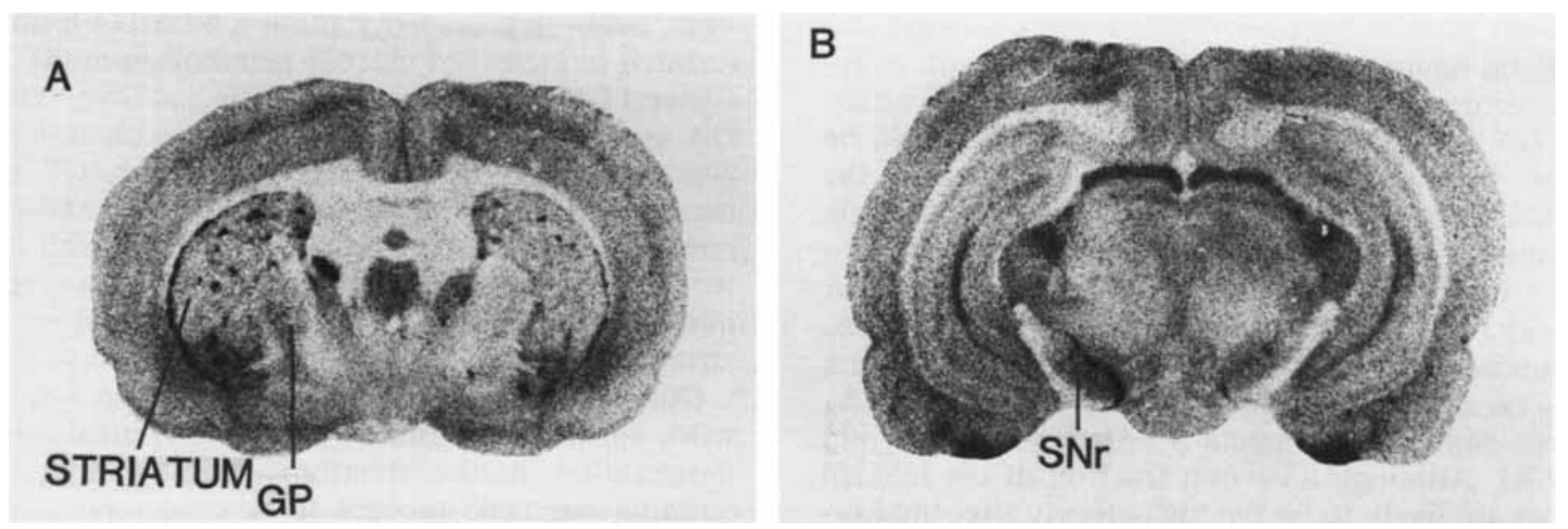

FIG. 6. Autoradiograms of $\left[{ }^{3} \mathrm{H}\right]$ naloxone $(6 \mathrm{nM})$ binding in coronal sections containing GP (A) and SNr (B) 4 weeks after 6OHDA lesions in the right MFB. Binding was decreased in both GP and SNr ipsilateral to the lesion. Note the disappearance of patch-like binding in the striatum. $\times 5$.

determined by measuring DA levels, DA high-affinity uptake, or tyrosine hydroxylase activity (Creese and Snyder, 1979; Heikkila et al., 1981; Wooten and Collins, 1981, 1983). This necessity for complete lesions presumably reflects the robust compensatory responses of the nigrostriatal DA system to lesions (Hornykiewicz, 1981). Our studies showed changes in DA receptors after 6OHDA similar to those described previously.

Other neurotransmitter receptors in the denervated striatum and its projection areas have been studied only to a limited extent after nigrostriatal lesions. We found that opiate receptors in "nonpatch" and "patch" striatum were decreased. Five months after lesions, there was nearly the complete disappearance of patch-like $\left[{ }^{3} \mathrm{H}\right]$ naloxone binding in the striatum ipsilateral to the lesion. This change in binding pattern may indicate that $\mu$-opiate receptors are localized in part presynaptically on DA terminals (Pollard et al., 1977; Murrin et al., 1980) or alternatively that selective postsynaptic dendritic degeneration has occurred (Hattori and Fibiger, 1982). The changes of opiate receptors in GP, EPN, and $\mathrm{SNr}$ were not predicted and the significance of these changes is unclear. One possible explanation for the opiate receptor findings is that DA inputs may inhibit striatal opiate cells. In this case MFB lesions would cause disinhibition of these neurons and subsequent down-regulation of opiate receptors in GP, EPN, and $\mathrm{SNr}$.

There is controversy as to whether DA is excitatory or inhibitory on postsynaptic cells (McLennan and York, 1967; Connor, 1970; Cools and van Rossum, 1980; Kitai, 1981; Scheel-Kruger, 1983; Schoener and Elkins, 1984). If DA is inhibitory on GABAergic striatal output cells, then the re-

TABLE 2. Time course of changes in $\left.l^{3} H\right]$ naloxone and $\left.l^{3} H\right] D A D L$ binding to in striatum and its projection areas in $M F B$-lesioned rat brains

\begin{tabular}{|c|c|c|c|c|c|c|c|}
\hline \multirow[b]{3}{*}{$\begin{array}{l}\text { Time after } \\
\text { lesions }\end{array}$} & \multirow[b]{3}{*}{ Structures } & \multicolumn{2}{|c|}{$\left[{ }^{3} \mathrm{H}\right]$ Naloxone } & \multirow[b]{3}{*}{$\mathrm{p}^{b}$} & \multicolumn{2}{|c|}{$\left[{ }^{3} \mathrm{H}\right] \mathrm{DADL}$} & \multirow[b]{3}{*}{$\mathrm{p}^{b}$} \\
\hline & & Intact side $e^{a}$ & $\begin{array}{l}\text { Ipsilateral } \\
\text { to lesion }\end{array}$ & & Intact side ${ }^{a}$ & $\begin{array}{l}\text { Ipsilateral } \\
\text { to lesions }\end{array}$ & \\
\hline & & $\begin{array}{c}\text { Bound } \\
\text { (fmol/mg protein) }\end{array}$ & $\begin{array}{l}\text { Percent } \\
\text { intact side }\end{array}$ & & $\begin{array}{c}\text { Bound } \\
\text { (fmol/mg protein) }\end{array}$ & $\begin{array}{l}\text { Percent } \\
\text { intact side }\end{array}$ & \\
\hline 1 week & $\begin{array}{l}\text { Striatum } \\
\text { GP } \\
\text { SNr }\end{array}$ & $\begin{array}{l}126 \pm 19 \\
121 \pm 24 \\
159 \pm 28\end{array}$ & $\begin{array}{l}69 \pm 8 \\
60 \pm 7 \\
96 \pm 6\end{array}$ & $\begin{array}{l}<0.02 \\
<0.001 \\
\quad \text { NS }\end{array}$ & $\begin{array}{l}309 \pm 32 \\
151 \pm 21 \\
112 \pm 15\end{array}$ & $\begin{array}{l}51 \pm 5 \\
43 \pm 8 \\
95 \pm 7\end{array}$ & $\begin{array}{c}<0.001 \\
<0.001 \\
\quad \text { NS }\end{array}$ \\
\hline 4 weeks & $\begin{array}{l}\text { Striatum } \\
\text { GP } \\
\text { EPN } \\
\text { SNr }\end{array}$ & $\begin{array}{l}122 \pm 6 \\
153 \pm 10 \\
247 \pm 14 \\
166 \pm 9\end{array}$ & $\begin{array}{l}90 \pm 4 \\
56 \pm 2 \\
81 \pm 5 \\
93 \pm 4\end{array}$ & $\begin{array}{c}<0.01 \\
<0.01 \\
<0.05 \\
\text { NS }\end{array}$ & $\begin{aligned} 329 & \pm 15 \\
143 & \pm 6 \\
123 & \pm 25 \\
96 & \pm 5\end{aligned}$ & $\begin{array}{l}71 \pm 3 \\
52 \pm 3 \\
66 \pm 8 \\
83 \pm 4\end{array}$ & $\begin{array}{c}<0.001 \\
<0.001 \\
\text { NS } \\
<0.02\end{array}$ \\
\hline 5 months & $\begin{array}{l}\text { Striatum } \\
\text { SNr }\end{array}$ & $\begin{array}{l}146 \pm 16 \\
134 \pm 8\end{array}$ & $\begin{array}{l}68 \pm 7 \\
68 \pm 3\end{array}$ & $\begin{array}{l}<0.05 \\
<0.01\end{array}$ & $\begin{array}{c}212 \pm 24 \\
-\end{array}$ & $\begin{array}{c}68 \pm 4 \\
-\end{array}$ & $<0.001$ \\
\hline
\end{tabular}

Data represent the means \pm SEM of four to six animals.

${ }^{a}$ Values represent amount bound at $6 \mathrm{nM}\left[{ }^{3} \mathrm{H}\right]$ naloxone or $\left[{ }^{3} \mathrm{H}\right] \mathrm{DADL}$. Sections through GP and EPN were not available at all time points.

${ }^{b}$ Two-tailed paired Student's $t$ test; NS, not significant. 
moval of this inhibitory effect should cause the striatal neurons to be overactive and result in receptor down-regulation in striatal projection areas. If DA is excitatory, then the opposite should be true. In this study, we examined the effect of the removal of DA input to striatum on GABAergic output to GP, EPN, and SNr. We used $\left[{ }^{3} \mathrm{H}\right]$ muscimol binding to measure GABA receptors. Our assay measured predominantly low-affinity sites. Muscimol labels low-affinity $\mathrm{GABA}_{\mathrm{A}}$ sites with a $K_{\mathrm{D}}$ of about $50 \mathrm{nM}$ and the high-affinity $\mathrm{GABA}_{\mathrm{A}}$ sites with a $K_{\mathrm{D}}$ of about $5 \mathrm{n} M$ (Beaumont et al., 1978). Although a certain fraction of the labeled sites are likely to be the high-affinity site, the lowaffinity site is a major component in our studies (Pan et al., 1983). We found that there were major differences in the response of GP, EPN, and SNr to the loss of DA input. GABA and BDZ receptors were down-regulated in striatum and GP but were up-regulated in EPN and SNr. These changes in EPN and $\mathrm{SNr}$ are unlikely to have occurred secondary to direct damage of the striatonigral GABAergic pathway, as the lesions did not produce degenerating terminals in the $\mathrm{SNr}$ as determined by Fink-Heimer degeneration studies. Thus, dopaminergic input seemed to have an inhibitory effect on intrinsic striatal GABAergic connections and on GABAergic neurons that project to GP. In contrast, DA appeared to have an excitatory effect on striatal GABAergic output to EPN and SNr because MFB lesions caused up-regulation of GABA and $\mathrm{BDZ}$ receptors in these two areas. These receptor findings suggest that striatal output may be compartmentalized and that DA affects the outputs in contrasting manners.

Interestingly, behavioral, biochemical, and glucose metabolism studies have also suggested such a differentiation. Behavioral experiments have reported apparent DA activation of striatoentopeduncular and striatonigral pathways and apparent DA inhibition of striatopallidal neurons, although few studies have examined the effects of DA on striatal output to all three areas simultaneously (Cools and van Rossum, 1980; Scheel-Kruger, 1983). Biochemical studies of animals treated chronically with neuroleptics (which block DA receptors) have suggested that whereas the striatopallidal GABAergic pathway seems to be disinhibited by this treatment (Mao et al., 1977; Marco et al., 1978), the striatonigral GABAergic pathway is inhibited by it (Maggi et al., 1977; Coward, 1982; Nicoletti et al., 1981). Some investigators have found GABA receptor increases in $\mathrm{SNr}$ after neuroleptic treatment (Gale, 1980; Loonen et al., 1981; Huffman and Ticku, 1983 ) but GP has not been investigated. Finally, deoxyglucose uptake studies have suggested that output from striatum to GP is affected differently from output to SNr and EPN (Wooten and Collins,
1981, 1983). In these latter studies, 6-OHDA lesions resulted in increased glucose metabolism in the ipsilateral GP with no change in EPN and SNr. When DA agonists were given to animals with lesions, glucose metabolism returned to normal in GP and increased in EPN and SNr. The behavioral and glucose metabolism studies, in conjunction with our receptor studies, suggest that DA inputs normally inhibit striatopallidal projection neurons and excite striatoentopeduncular and striatonigral pathways.

Our results are particularly intriguing in light of work showing anatomical and biochemical inhomogeneities in the striatum. Traditionally, the striatum has been thought to be cytoarchitectonically and neurochemically homogeneous. Recently, anatomic evidence has pointed to cytoarchitectonic compartmentation of the striatum into clusters, patches, or islands in developing and adult animals (Kunzle, 1975; Mensah, 1977; Graybiel et al., 1979; Goldman-Rakic, 1981). Histochemical stains for acetylcholinesterase, enkephalins, and substance $P$ as well as autoradiographic localization of receptors in the striatum support the anatomical findings (Olson et al., 1972; Pert et al., 1975, 1976; Graybiel et al. 1981a, $b$; Herkenham and Pert, 1981; Nastuk and Graybiel, 1983; Murrin and Ferrer, 1984; van der Kooy et al., 1984). In the developing striatum, one major presumptive GABAergic striatal output pathway (to $\mathrm{SNr}$ ) appears to originate from patches receiving DA input (Fishell and van der Kooy, 1984). The ontogeny of the remaining GABAergic striatal efferent cells is still unknown. The anatomical and neurochemical inhomogeneities in the striatum may reflect selective interactions between neurotransmitter systems and neuronal groups. In view of our data, one striatal compartment may contain striatopallidal neurons that would normally be inhibited by DA and another striatal compartment may contain striatoentopeduncular and striatonigral neurons that would be excited by DA.

Striatal lesions and MFB 6-OHDA lesions in animals are models for the human neurodegenerative disorders. Huntington's disease and Parkinson's disease, respectively (Ungerstedt, 1971b; Schwarcz and Coyle, 1977; McGeer et al., 1978, 1984; Hornykiewicz, 1981). The primary GABA and BDZ receptor changes that differentiate the rodent models for Huntington's disease and for Parkinson's disease are the $\mathrm{GABA} / \mathrm{BDZ}$ receptor changes seen in GP. GABA and BDZ receptors in $\mathrm{SNr}$ and EPN react similarly to the two lesions. It was surprising that two lesions, which produce clinically opposite syndromes (McGeer and McGeer, 1976; Penney and Young, 1983), share the same receptor changes in the SNr and EPN (two major output areas of the basal ganglia). Possibly, GABAergic output to the GP will be found to be most important in the generation of the chorea seen in Huntington's 
disease or the bradykinesia and rigidity seen in Parkinson's disease whereas the GABAergic output to $\mathrm{EPN} / \mathrm{SNr}$ will be found more important for other motor problems such as dystonia which is seen in both Parkinson's and Huntington's diseases.

Acknowledgment: This work was supported by NSF grant BNS-8118765 and a University of Michigan minority fellowship and NIMH predoctoral National Research Service Award I F 31 MH09137-01 to H.S.P.

\section{REFERENCES}

Abou-Khalil B., Young A. B., and Penney J. B. (1984) Evidence for the presynaptic localization of opiate binding sites on striatal efferent fibers. Brain Res. 323, 21-29.

Beaumont K., Chilton W. S., Yamamura H. I., and Enna S. J. (1978) Muscimol binding in rat brain: association with synaptic GABA receptors. Brain Res. 148, 153-162.

Biggio G., Corda M. D., Concas A., and Gessa G. L. (1981) Denervation supersensitivity for benzodiazepine receptors in the rat substantia nigra. Brain Res. 220, 344-349.

Breese G. R. and Traylor T. D. (1971) Depletion of brain noradrenalin and dopamine by 6-hydroxydopamine. Br. J. Pharmacol. 42, 88-99.

Connor J. D. (1970) Caudate nucleus neurons: correlation of the effects of substantia nigra stimulation with iontophoretic dopamine. J. Physiol. 208, 641-703.

Cools A. R. and van Rossum J. M. (1980) Multiple receptors for brain dopamine in behavior regulation: concept of dopamine-E and dopamine-I receptors. Life Sci. 27, 1237-1253.

Coward D. M. (1982) Classical and non-classical neuroleptics induce supersensitivity of nigral GABAergic mechanisms in the rat. Psychopharmacology 78, 180-184.

Creese I. and Synder S. H. (1979) Nigrostriatal lesions enhance striatal $\left[{ }^{3} \mathrm{H}\right]$ apomorphine and $\left[{ }^{3} \mathrm{H}\right]$ spiroperidol binding. Eur. J. Pharmacol. 56, 277-281.

Creese I., Burt D. R., and Snyder S. H. (1977) Dopamine receptor binding enhancement accompanies lesion-induced behavioral supersensitivity. Science 197, 596-598.

Dahistrom A. and Fuxe K. (1964) Evidence for the existence of monoamine-containing neurons in the central nervous system. Acta Physiol. Scand. 62 (Suppl. 232), 1-55.

Dauth G. W., Frey K. A., and Gilman S. (1983) A densitometer for quantitative autoradiography. $J$. Neurosci. Methods 9, $243-251$.

Dray A. (1980) The physiology and pharmacology of mammalian basal ganglia. Prog. Neurobiol. 14, 221-336.

Feger J. and Crossman A. R. (1984) Identification of different subpopulations of the neostriatal neurons projecting to globus pallidus or substantia nigra in the monkey. Neurosci. Lett. 49, 7-12.

Fink R. P. and Heimer L. (1967) Two methods for selective silver impregnation of degenerating axons and their synaptic endings in the central nervous system. Brain Res. 4, 369-374.

Fishell G. and van der Kooy D. (1984) Caudate efferents in perinatal rats originate primarily from patches receiving dopamine input. Soc. Neurosci. Abstr. 10, 704.

Fonnum F., Gottesfeld Z., and Grofova I. (1978) 1. Distribution of glutamate decarboxylase, choline acetyltransferase and aromatic amino acid decarboxylase in the basal ganglia of normal and operated rats. Evidence for striatopallidal, striatoentopeduncular, and striatonigral GABAergic fibers. Brain Res. 143, 125-138.

Gale K. (1980) Chronic blockade of dopamine receptors by antipsychotic drugs enhances GABA binding in substantia nigra. Nature 283, 569-570.

Goldman-Rakic P. S. (1981) Prenatal formation of cortical input and development of cytoarchitectonic compartments in the neostriatum of the rhesus monkey. J. Neurosci. 1, 721-735.
Graybiel A. M. and Ragsdale C. W. Jr (1983) Biochemical anatomy of the striatum, in Chemical Neuroanatomy (Emson P. C., ed.), pp. 427-504. Raven Press, New York.

Graybiel A. M., Ragsdale C. W. Jr., and Edley S. M. (1979) Compartments in the striatum of the cat observed by retrograde cell labeling. Exp. Brain Res. 34, 189-195.

Graybiel A. M., Ragsdale C. W. Jr., Yoneoka E. S., and Elde R. P. (1981a) An immunohistochemical study of enkephalins and other neuropeptides in the striatum of the cat with evidence that the opiate peptides are arranged to form mosaic patterns in register with the striasomal compartments visible by acetylcholinesterase staining. Neuroscience 6, 377-397.

Graybiel A. M., Pickel V. M., Joh T. H., Reis D. J., and Rags. dale D. W. Jr. (1981b) Direct demonstration of a correspondence between the dopamine islands and acetylcholinesterase patches in the developing striatum. Proc. Natl. Acad. Sci. USA 78, 5871-5875.

Grofova I. (1975) The identification of striatal and pallidal neurons projecting to substantia nigra. An experimental study by means of retrograde axonal transport of horseradish peroxidase. Brain Res. 91, 286-291.

Guidotti A., Gale K., Suria A., and Toffano G. (1979) Biochemical evidence for two classes of GABA receptors in rat brain. Brain Res. 172, 566-571.

Hattori T. and Fibiger H. C. (1982) On the use of lesions of afferents to localize neurotransmitter receptor sites in the striatum. Brain Res, 238, 245-250.

Hattori T., Singh V. K., McGeer E. G., and McGeer P. L. (1976) Immunohistochemical localization of choline acetyltransferase containing neostriatal neurons and their relationship with dopaminergic synapses. Brain Res. 102, 164-173.

Heikkila R. E., Shapiro B. S., and Duvoisin R. C. (1981) The relationship between loss of dopamine nerve terminals, striatal $\left[{ }^{3} \mathrm{H}\right]$ spiroperidol binding and rotational behavior in unilaterally 6-hydroxydopamine lesioned rats. Brain Res. 211, 285-292.

Herkenham M. and Pert C. B. (1981) Mosaic distribution of opiate receptors, parafascicular projections and acetylcholinesterase in rat striatum. Nature 291, 415-418.

Hornykiewicz O. (1981) Brain neurotransmitter changes in Parkinson's disease, in Movement Disorders (Marsden C. D and Fahn S., eds), pp. 4-58; Butterworths, London.

Huffman R. D. and Ticku M. K. (1983) The effects of chronic haloperidol administration on GABA receptor binding. Pharmacol. Biochem. Behav. 19, 199-204.

Kitai S. T. (1981) Electrophysiology of the corpus striatum and brain stem integrating system, in Handbook of Physiology, Vol. II (Geiger S. R., executive ed), pp. 997-1015. William \& Wilkins, Baltimore.

Konig J. F. R. and Klippel R. A. (1963) The Rat Brain: Krieger, Huntington, New York.

Kuhar M. J. (1973) Neurotransmitter uptake: a tool in identifying neurotransmitter-specific pathways. Life Sci. 13, 16231634.

Kunzle H. (1975) Bilateral projections from precentral motor cortex to the putamen and other parts of the basal ganglia. Brain Res. 88, 195-210.

Lo M. M. S., Niehoff D. L.. Kuhar M. J., and Snyder S. H. (1983) Differential localization of type I and type II benzodiazepine binding sites in substantia nigra. Nature 306 , $57-60$.

Loonen A. J. M., Soe-Agnie C. J., and Soudijn W. (1981) Effects of halopemide on GABA receptor binding, uptake and release. Brain Res. 210, 485-492.

Maggi A., Cattabeni F., Bruno F., and Racagni G. (1977) Haloperidol and clozapine: specificity of action on GABA in the nigrostriatal system. Brain Res. 133, 382-385.

Mao C. C., Cheney D. L., Marco E., Revuelta A., and Costa E. (1977) Turnover times of gamma-aminobutyric acid and acetylcholine in nucleus caudatus, nucleus accumbens, globus pallidus and substantia nigra: effects of repeated administration of haloperidol. Brain Res. 132, 375-379. 
Marco E., Mao C. C., Revuelta A., Peralta E., and Costa A. (1978) Turnover rates of $\gamma$-aminobutyric acid in substantia nigra, $n$. caudatus, globus pallidus and $n$. accumbens of the rats injected with cataleptogenic and non-cataleptogenic antipsychotics. Neuropharmacology 17, 589-596.

McGeer P. L. and McGeer E. G. (1976) Enzymes associated with the metabolism of catecholamines, acetylcholine and GABA in human controls and patients with Parkinson's disease and Huntington's chorea. J. Neurochem. 26, 65-76.

McGeer P. L., Eccles J. C., and McGeer E. G. (1978) Molecular Neurobiology of the Mammalian Brain, pp. 445-460. Plenum Press, New York

McGeer E. G.. Staines W. A., and McGeer P. L. (1984) Neurotransmitters in the basal ganglia. Can. J. Neurol. Sci. 11, $89-99$.

McLennan H. and York D. H. (1967) The action of dopamine on neurons of the caudate nucleus. J. Physiol. (Lond.) 189, $393-402$.

Mensah P. L. (1977) The internal organization of the mouse caudate nucleus: evidence for cell clustering and regional variations. Brain Res. 137, 53-66.

Murrin L. C. and Ferrer J. R. (1984) Ontogeny of the rat striatum: correspondence of dopamine terminals. opiate receptors and acetylcholinesterase. Neurosci. Lett. 47, 155160.

Murrin L. C., Coyle J. T., and Kuhar M. J. (1980) Striatal opiate receptors: pre- and postsynaptic localization. Life Sci. 27. $1175-1183$

Nagy J., Carter D., and Fibiger H. (1978) Anterior striatal projections to the globus pallidus, entopeduncular nucleus and substantia nigra in the rat. The GABA connection. Brain Res. 158, 15-29.

Nastuk M. A. and Graybiel A. M. (1983) The distribution of muscarinic binding sites in the feline striatum and its relationship to other histochemical staining patterns. Soc. Neurosci. Abstr. 9, 15.

Neve K. A. and Marshall J. F. (1984) The effects of denervation and chronic haloperidol treatments on neostriatal dopamine receptor density are not additive in rat. Neurosci. Lett. $\mathbf{4 6}$, 77-83.

Nicoletti F. Patti F., Condorelli D. F., Rampello L., Giammona G., Di Giorgio R.-M.. Canonico P. L., and Scapagnini U. (1981) Comparative effects of chronic haloperidol and sulpiride treatment on nigral and striatal GABA content. $J$. Neurochem. 37, 1048-1051.

Olson L., Seiger A., and Fuxe K. (1972) Heterogeneity of striatal and limbic dopamine innervation: highly fluorescent islands in developing and adult rats. Brain Res. 44, 283-288.

Pan H. S., Frey K. A., Young A. B., and Penney J. B. Jr. (1983) Changes in $\left[{ }^{3} \mathrm{H}\right]$ muscimol binding in substantia nigra, entopeduncular nucleus, globus pallidus and thalamus after striatal lesions as demonstrated by quantitative receptor autoradiography. J. Neurosci. 3, 1189-1198.

Pan H. S., Young A. B., and Penney J. B. (1984a) Characterization of benzodiazepine receptor changes in substantia nigra. globus pallidus and entopeduncular nucleus after striatal lesions. J. Pharmacol. Exp. Ther. 230, 768-775.

Pan H. S., Dauth G. W., Young A. B., and Penney J. B. (1984b) Computer-assisted estimates of lesion sizes and shrinkage in denervated areas from receptor autoradiograms using a digitizing tablet. Neurosci. Lett. 44, 277-280.

Parent A., Bouchard C., and Smith Y. (1984) The striatopallidal and striatonigral projections: two distinct fiber systems in primate. Brain Res. 303, 385-390.

Park M. R., Lighthall J. W., and Kitai S. T. (1980) Recurrent inhibition in the rat neostriatum. Brain Res. 194, 359-369.

Penney J. B. Jr. and Young A. B. (1983) Speculations on the functional anatomy of basal ganglia disorders. Annu. Rev. Neurosci. 6, 73-94.

Pert C. B., Kuhar M. J., and Snyder S. H. (1975) Autoradio- graphic localization of the opiate receptor in rat brain. Life Sci. 16, 1849-1854.

Pert C. B., Kuhar M. J., and Snyder S. H. (1976) Opiate receptor: autoradiographic localization in rat brain. Proc. Natl. Ac'ad. Sci. USA 73, 3729-3733.

Pickel V. M., Beckley S. C., Joh T. J., and Reis D. J. (1981) Ultrastructural immunocytochemical localization of tyrosine hydroxylase in the neostriatum. Brain Res. 225, 373385

Pollard H., Llorens-Cortes C., and Schwartz J. C. (1977) Enkephalin receptors on dopaminergic neurons in rat striatum. Nature 268, 745-747.

Preston R. J., Bishop G. A., and Kitai S. T. (1980) Medium spiny neuron projection from the rat striatum: An intracellular horseradish peroxidase study. Brain Res. 183, 253263

Reches A., Wagner R. H., Jackson V., Yablonskaya-Alter E., and Fahn S. (1983) Dopamine receptors in the denervated striatum: further supersensitivity by chronic haloperidol treatment. Brain Res. 275, 183-185.

Scheel-Kruger J. (1983) The GABA receptor and animal behavior, in The GABA Receptors (Enna S. J., ed), pp. 215256. Humana Press, New Jersey.

Schoener E. P. and Elkins D. P. (1984) Neuronal response to dopamine in rat neostriatum. A push-pull perfusion study. Neuropharmacology 23, 611-616.

Schwarcz R. and Coyle J. T. (1977) Striatal lesions with kainate acid: neurochemical characteristics. Brain Res. 127, 235249.

Shibuya H., Gale K., and Pert C. B. (1980) Supersensitivity to GABA's effect on benzodiazepine receptors develops after striatonigral lesions. Eur. J. Pharmacol. 62, 243-244.

Somogyi P., Bolam J. P., and Smith A. D. (1981) Monosynaptic cortical input and local axon collaterals of identified striatonigral neurons. A light and electron microscopic study using the Golgi-peroxidase transport-degeneration procedure. J. Comp. Neurol. 195, 567-584.

Stadler H., Lloyd K. G., Gadea-Ciria M., and Bartholini G. (1973) Enhanced striatal acetylcholine release by chlorpromazine and its reversal by apomorphine. Brain Res. 55, $476-480$.

Staunton D. A., Magistretti P. J., Koob G. F., Shoemaker W. J., and Blood F. (1982) Dopaminergic supersensitivity induced by denervation and chronic receptor blockade is additive. Nature 299, 72-74.

Ungerstedt U. (1971a) Stereotaxic mapping of the monoamine pathways in the rat brain. Acta Physiol. Scand. 197 (Suppl. 367), $1-48$.

Ungerstedt U. (1971b) Post-synaptic supersensitivity after 6-hydroxydopamine induced degeneration of the nigrostriatal dopamine system in the rat brain. Acta Physiol. Scand. 197 (Suppl. 367), 69-93.

van der Kooy D., Lanca A. J., and Kolb B. E. (1984) Mechanisms underlying the development and maintenance of a patchy striatal organization. Soc. Neurosci. Abstr. 10, 704.

Waddington J. L. and Cross A. J. (1978) Denervation supersensitivity in the striatonigral GABA pathway. Nature $76,618-$ 620.

Waddington J. L. and Cross A. J. (1980) Characterization of denervation supersensitivity in the striatonigral GABA pathway of the kainic acid-lesioned rat and in Huntington's disease. Brain Res. Bull. 5, 825-828.

Waszczak B. L., Hume C., and Walters J. R. (1981) Supersensitivity of substantia nigra pars reticulata to GABAergic drugs after striatal lesions. Life Sci. 28, 2411-2420.

Wooten G. F. and Collins R. C. (1981) Metabolic effects of unilateral lesion of the substantia nigra. J. Neurosci. 1, 285291.

Wooten G. F. and Collins R. C. (1983) Effects of dopamine stimulation on functional brain metabolism in rats with unilateral substantia nigra lesions. Brain Res. 263, 267-275. 